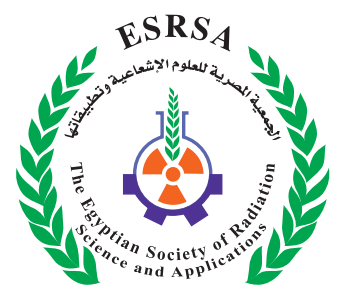

J. Nucl. Tech. Appl. Sci., Vol. 7, PP. 65 : 78 (2019)

\title{
Biocontrol Potential of some Entomopathogenic Fungi against The Cotton Leaf Worm Spodoptera littoralis in vitro
}

Hazaa, M.A.M. ${ }^{1}$; Mohsen, E.I. ${ }^{2}$; AlmEl-din, M.M.S. ${ }^{1}$; Hassan, R.S. ${ }^{1}$ and Ashoush, S.R.M. ${ }^{1}$

Received: 30/12/2018

Accepted: 13/02/2019

E.mail:hythym_1984@yahoo.com

\section{KEYWORDS}

Entomopathogenic

Fungi, Spodoptera

Littoralis, Biocontrol,

Czapek>s Agar,

Protease Enzyme,

Gamma Irradiation.

\section{ABSTRACT}

The objective of this study was to isolate and identify the entomopathogenic fungi as biocontrol agents and to evaluate their pathogenicity against the cotton leaf worm, Spodoptera littoralis (Boisd.). Six strains of fungi were isolated from healthy and infected plants using dilution plate method. Czapek's agar supplemented with $0.5 \%$ yeast extract and potato dextrose agar, amended with rose bengal (1/15000) and chloramphenicol $(50 \mathrm{ppm})$ was used for primary isolation. Aspergillus tamarii, Aspergillus parasiticus, pencillium sp., Trichoderma harzianum,Cladosporium $\mathrm{sp}$ .and Rhizopus sp. were isolated. Results showed that A.parasiticus, A. tamarii, T. harzianum and Pencillium sp. are the most promonent so in this study we test their virulence against third instar larvae of the cotton leaf worm the mortality percentage were calculated for each fungus using $1 \times 10^{6}, 1 \times 10^{7}$ and $1 \times 10^{8}$ spore per $\mathrm{ml}$. It is clear from the results that the mortality percentage increased with elapsing time. The high mortality percentage recorded is $86.66 \%$ for A.tamarii at $1 \times 10^{8}$ spore/ $\mathrm{ml}$ then $83.33 \%$ with A.parasiticus at $1 \times 10^{7}$ spore $/ \mathrm{ml}, 80 \%$ for $T$. harizianum at $1 \times 10^{6} \mathrm{spore} / \mathrm{ml}$ and $40 \%$ at $1 \times 10^{7} \mathrm{spore} / \mathrm{ml}$ for Pencillium sp. Comparison to these fungi clear that concentration $10^{7}$ give the highest mortality percentage to the cotton leaf worm for all except A.tamarii.Then screening to the ability of these fungi to produce protease enzyme reveals that all of them produce protease enzyme except Pencillium sp. Gamma irradiation was used to enhance the protease enzyme activity and consequently increase the mortality percentage.

1. Biological Application Department, Nuclear Research Center, Atomic Energy Authority, Egypt.

2. Department of Botany, Faculty of Science, Universiry of Port Said, Port Said, 42524,EGypt. 
The dose level of 1200 Gy increase protease activity of $A$. tamarii from 0.433 to 1.366 so mortality percentage of third instar larvae of Spodoptera littoralis increased from $43.33 \%$ to $86.66 \%$ at concentration $1 \times 10^{7}$ of spore suspension irradiated with 1200 Gy dose level..

\section{INTRODUCTION}

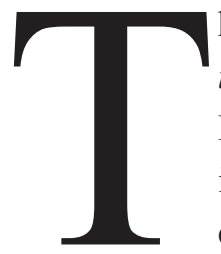

he Egyptian cotton leaf worm Spodoptera littoralis (Boisd.), (Noctuidae, Lepidoptera) is a serious, polyphagous insect, which has a high reproductive capacity. It is an economically important pest of many agricultural crops; it can attack 112 plant species belonging to 44 families (Mallik arjuna et al., 2004). Development of an effective control method against the cotton leaf worm, Spodoptera littoralis is urgently needed since it causes serious damage to many important agricultural crops in Egypt. An interest in using of microbial insecticides for biological control of insect pests, as alternatives to chemical control, since they neither leave toxic chemical residues in the environment nor induce resistance in their insect hosts (Evans, 1999). And hence, the public awareness and concern for environmental quality, has led to more focused attention on research aiming at developing biological agents (Hidalgo et al., 1998). The biological plant protection with entomopathogenic fungi has key role in sustainable pest management program. Entomopathogenic fungi as biocontrol agents have several advantages when compared with conventional insecticides. These include low cost, high efficiency, safety for beneficial organisms, reduction of residues in environment, and increase biodiversity in human managed ecosystems (Lacey et al., 2001). Fungal biocontrol agents have unique mode of infection. Incontrast to bacteria and viruses, they are capable of attacking all developmental stages of insects (Anand et al., 2008; Ferron, 1978(. They also, do not need to be ingested dy insects and can invade their host directly through the cuticle. That is why entomopatho- genic fungi are capable of infecting non feeding mesh like eggs (Ujian and Shahzad, 2007; Anand and Tiwary, 2009) and pupae of insects (Nguyen et al., 2007; Anand et al., 2008). Fungal biological control agents have demonstrated efficacy against a wide range of insect pests including Spodoptera species (Purwar and Sachan, 2005; Lin et al., 2007; Amer et al., 2008). Entomopathogenic fungi (EPF) have been found in many diverse habitats and associated with a broad range of insect hosts (Samson et al., 1988). These habitats include aquatic, forest and agricultural ecosystems that are of direct importance to insect control and crop protection (Bin and Mitsuaki, 2006 \& Palomares et al., 2014) The identification, isolation and characterization of EPF from these ecosystems are driven by a need to fully understanding the roles of these fungi within their natural environments. Only with this knowledge we can attempt to utilize EPF for the control of insect pests. Enzyme secretion is believed to be a key factor in determining the virulence of the isolate and this is considered as a rationale for the enhance virulence of certain isolates (Mustafa and Kaur, 2009). Highly pathogenic strains show detectable amounts of extracellular chitinase, lipase, and protease activities (Samuels et al., 1989).

The objective of the present study was to isolate and identify the entomopathogenic fungi species as biocontrol agents, and to test the efficacy of the isolated native strains to produce protease enzyme and consequently killing activity to Spodoptera littoralis under laboratory conditions.Finally enhancement of these activity by gamma irradiation.

\section{MATERIALS AND METHODS}

\section{Insect Rearing}

The culture of the tested insect of Spodoptera littoralis was initiated from egg-masses collected from infested cotton field at Qualubia Governorate and reared in the Nuclear Research Center (Inshas), Sharkia Gover- 
norate. Ricinus communis, leaves were introduced as food for the newly hatched larvae. Cotton leaf worm larvae were transferred daily to new clean jars, provided with fresh castor oil plant leaves and kept under the laboratory conditions of $27 \pm 2^{\circ} \mathrm{C}$ and 60 65 R.H. Daily observation was carried out until the $3^{\text {th }}$ larval instar.

\section{Isolation of Entomopathogenic Fungi From plants}

\section{Collection of Plant samples}

Plant samples were collected from different places. Healthy and diseased Cabbage, Alfafa, Maize and Ricinus communis leaves were transferred to the laboratory in tight sterilized polyethylene bags and kept at low temperature until plating. All colt lected samples were from Abou Zabal AlQualubia Governorate except the last sample which is from Abou Zabal AlQualubia Governorate and Egyption Atomic Energy Authority Inshas.

\section{Isolation of Fungi}

Fungi were isolated by using dilution plate method Johnson et al. (1960) in which six plates were used for isolating/sample. Czapek's agar supplemented with $0.5 \%$ yeast extract (CYA) and potato dextrose agar (PDA), amended with rose bengal (1/15000) and chloramphenicol (50 ppm) was used for primary isolation. Plates were incubated at $28{ }^{\circ} \mathrm{C}$ for 10 days and developing fungi were counted. For maintaining cultures and for proper identification, pure cultures of isolated fungi were grown on standard media such as Vegetable Agar (VA), Oatmeal Agar (OA), Malt Extract Agar (MEA) Potato Dextrose Agar (PDA) and Potato Carrot Agar (PCA).

\section{Identification of the isolated fungi}

Taxonomic identification by morphology of fungal isolates was mainly based on the following identification keys: Raper and Thom (1949), Pitt (1980) for Penicillium ;Raper and Fennell (1965) for Aspergillus ; Ellis (1971 and 1976) for dema- tiaceous hyphomycetes; Arx (1981); Domsch et al. (1980) for miscellaneous fungi. The systematic arrangement follows the last system of classification appearing in the $9^{\text {th }}$ edition of Anisworth \& Bisby's Dictionary of the fungi (Kirk et al., 2001).

\section{Media used for growth of fungal microorganisms}

Abasal medium (Czapek's-Dox) of the following composition ( $\mathrm{g} / \mathrm{l}$ ) was used: Sodium nitrate, 2.0; potassium dihydrogen phosphate, 1.0; potassium chloride, 0.5 ; ferrous sulphate, 0.01 ; magnesium sulphate, 0.5 and sucrose, 30 ; made up in distilled water (Thom and Raper, 1945).

\section{Preparation of fungal inocula for fungal bioassays}

Conidia were harvested by scraping the sporulating colonies and suspended in sterile distilled water containing $1.0 \%$ Tween 80 (v/v aqueous solution, as wetting agent) (Hicks et al., 2001). The resulting conidial suspensions were first cleared for hyphal debris by filtration, using a suitable sterilized piece of clothes, and centrifugation for $5 \mathrm{~min}$ at $3000 \mathrm{rpm}$ then washed twice with $0.05 \%$ Tween 80 with intervening centrifugation. Resulting conidia were resuspended in $1.0 \%$ Tween 80 and the concentrations were determined using a haemacytometer before they were diluted with sterile water containing $1.0 \%$ Tween 80 to reach the appropriate concentrations $\left(1 \times 10^{6}, 1 \times\right.$ $10^{7}$ and $1 \times 10^{8}$ conidia $\left./ \mathrm{ml}\right)$. Conidial viability was examined prior to the experiments by placing three droplets of a $1 \times 10^{6}$ conidia spores ml-1suspension on to suitable agar plates followed by incubation for $24 \mathrm{~h}$ at $30^{\circ} \mathrm{C}$, after which, their germination was examined under a light microscope by observing less than $90 \%$ growth for all isolates.

\section{Bioefficacy of the isolated entomopathogenic

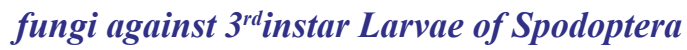 littoralis}

S. littoralis larvae were immersed individually for 30 seconds into a fungal suspension containing 
$\left(1 \times 10^{6}, 1 \times 10^{7}, 1 \times 10^{8}\right.$ conidia / ml). For the control treatment, larvae were dipped into a $0.1 \%$ Tween (80) solution. Treated larvae were allowed to crawl freely on tissue paper in a Petri dish to remove excess moisture. Then treated larvae were placed individually in small plastic containers $(3.5 \times 1.3 \mathrm{~cm})$. These containers were placed in crispers having wet towel paper to maintain humidity. All treated larvae were incubated at $27 \pm 1^{\circ} \mathrm{C}, 80 \pm 5 \%$, R.H. and photo phase of 12 hours. Excised parts of fresh Ricinus Comminus leaves surface sterilized with aqueous solution of sodium hypochlorite $(0.5 \% \mathrm{v} / \mathrm{v})$ then washed twice with distilled water were introduded as a food source for the larvae. Leaves were regularly replaced with fresh ones at an interval of 24 hours. Each treatment had batch of 10 larvae and replicated three times. Mortality data was recorded up to 10 days. The cadavers were incubated at $27 \pm 1^{\circ} \mathrm{C}$ in an incubator to investigate mycosis and sporulation of them. All fungi were isolated in Bioinsecticide laboratory, Biological Application Department, Nuclear Research Center (Inshas), Sharkia Governorate and identified in microbiology laboratory, Faculty of Science, Port Said University.

\section{Protease assay}

Protease activity was determined by Plate assay method (Anagnostakis, 1975). Production of proe teolytic enzymes was detected by using gelatin as protein source in growth medium. The fungal strain was spot inoculated in petri dishes with nutrient agar medium supplemented with $1 \%$ gelatin (Peptone, 5g; Beef extract, 3g; NaCl, 5g; Agar, 15g; Distilled water, 1 liter, $\mathrm{pH}$ 6). Prior to inoculation, the petri dishes were incubated at $28 \pm 1 \mathrm{oC}$ for 7 days. After a week of incubation, gelatin degradation was observed as a clearing zone around fungal colonies. This zone of gelatinolysis was seen clearly upon flooding the plate with aqueous saturated solution of mercuric chloride reagent $\left(15 \mathrm{~g} \mathrm{HgCl}_{2}\right.$ dissolved completely in $20 \mathrm{ml} 7 \mathrm{M}$ conc. $\mathrm{HCl}$, then raised to $100 \mathrm{ml}$ with sterile distilled water). Mercuric chlo- ride solution reacted with gelatin to produce a white precipitate which made the clearing zone visible. The clearing zone was measured as indicative of the extracellular protease activity of the fungal strain. Enzyme activity was measured by the following formula: $\mathrm{EA}=\mathrm{D}-\mathrm{d}$; D-diameter of colony plus clearing zone; d-diameter of colony.

\section{Effect of gamma radiation on protease enzyme activity}

\section{Source of Gamma rays for irradiation studies}

Gamma cell (Cobalt-60), located at Nuclear Research Center, Egyptian Atomic Energy Authority at Inshas, Egypt was used as a source of gamma rays at dose rate of $0.855 \mathrm{KGy} / \mathrm{h}$.

\section{Statistical analysis}

Data were analyzed statistically following standard procedures for analysis of variance. Differences among means were evaluated for significance according to Duncan's New Multiple Range Test at the $5 \%$ level of probability using COSTAT.

\section{RESULTS AND DISCUSSION}

Entomopathogens have been suggested as controlling agents of insect pests for over acentury. There has been an increasing interest in employing fungal pathogens to combat insect pests. New application and production in combined with a greater understanding of both fungal and insect ecology have shown that biological insecticides can now compete with traditional chemical pesticides much faster.

\section{Isolated Fungi}

In this study entomopathogenic fungi isolated from healthy and infected plants. In order to select the most proper fungal strains for controlling cotton leaf worm; fungal biota of healthy and infected leaves of host plants of that insect were surveyed. During this part of study, a total number of 11 species belong to 6 genera, has been isolated. Isolated 
fungi belong to three classes (Table 1) of which Hyphomycetes comes first where represented by 8 species accounting for $83.33 \%$ of the total isolated taxa. It is followed by classes Ascomycetes and $\mathbf{Z y -}$ gomycetes which is represented by only one species constituting $8.33 \%$ each. Many authers confirm these results of isolating fungi from the plant tissue as Saikkonen et al. (2004); Elliot et al. (2000) and White et al. (2002) who stated that endophytic fungi are often regarded as plant defending mutual- ists and discussed the presence of $B$. bassiana in internal plant tissue as an adaptive protection against herbivorous insects. Amin et al. (2014) who Studied the isolation and identification of fungal endophytes from healthy pods of cocoa plant and investigated their effects against the egg of cocoa pod borer , his results also indicated that there were five fungal endophytes genera as, Trichoderma sp., Fusarium sp., Beauveria sp., Aspergillus sp.

Table (1) : Number of isolated species.

\begin{tabular}{|c|c|c|c|c|}
\hline Classes & Healthy plants & Infected plants & Total & $\%$ \\
\hline Hyphomycetes & 7 & 8 & 8 & 80 \\
\hline Ascomycetes & - & 1 & 1 & 10 \\
\hline Zygomycetes & 1 & - & 1 & 10 \\
\hline Total number of species & 7 & 9 & 11 & 100 \\
\hline
\end{tabular}

\section{Species richness}

Species richness means the number of species belonging to each genus isolated throughout the current investigation. The genera recorded are given in Table (2). It is obviously evident, from the Table, that Aspergillus is the richest by showing a spectrum 6 species. However, the remaining genera represented only by one species each.Another work concide with these results were obtained by Leatherdale (1970),
Zimmerman (1993) and Smith et al. (1999) who stated that Hyphomycete fungal species, for example $B$. bassiana, were reported to infect insect pests from several orders and thereby play an important role in the regulation of pest populations. Ismail and Abdel-Sater (1993) also found that Aspergillus, the most frequent genus, was associated with all different insect stages.

Table (2): Genera and species richness of isolated fungi.

\begin{tabular}{|c|c|c|c|}
\hline No. of genera & $\begin{array}{c}\text { Healthy plants } \\
\text { No. of species }\end{array}$ & $\begin{array}{c}\text { Infected plants } \\
\text { No. of species }\end{array}$ & Total no. of species \\
\hline Aspergillus & 5 & 6 & 6 \\
\hline Penicillium & 1 & 1 & 1 \\
\hline Trichoderma & 1 & 1 & 1 \\
\hline Rhizopus & 1 & 0 & 1 \\
\hline Cladosporium & 1 & 0 & 11 \\
\hline Total & 9 & 8 & \\
\hline
\end{tabular}




\section{Total fungal count}

Fungal counts were expressed as total number of colony forming units per gram dry sample (cfu/g) of each species. In Table (3) a total number of six species was isolated from plants. In view of mean counts, the most domineny texa found in decreasing order were Penicillium sp.,Trichoderma harizianum, Aspergillus tamarii,Aspergillus parasiticus, Rhizopus sp. and cladosporium sp.

Table (3) : Mean count (cfu/g)* of fungi isolated from healthy and infected plants (infected by cotton leaf worm).

\begin{tabular}{|c|c|c|c|c|c|c|c|c|c|}
\hline \multirow{2}{*}{ Species } & \multicolumn{2}{|c|}{ Cabbage } & \multicolumn{2}{|c|}{ Alfalfa } & \multicolumn{2}{|c|}{ Ricinus } & \multicolumn{2}{|c|}{ Maize } & \multirow{2}{*}{ Mean } \\
\hline & Healthy & Infected & Healthy & Infected & Healthy & Infected & Healthy & Infected & \\
\hline $\begin{array}{c}\text { Penicillium } \\
\text { sp. }\end{array}$ & 25166 & 16666 & 31166 & - & - & - & - & - & $9124 \pm 4.7$ \\
\hline $\begin{array}{c}\text { Trichoderma } \\
\text { harizianum }\end{array}$ & 36667 & 167 & - & - & - & - & - & - & $4604 \pm 4.6$ \\
\hline $\begin{array}{c}\text { Aspergillus } \\
\text { tamarii }\end{array}$ & 333 & 166 & 166 & - & 333 & - & - & - & $124 \pm 0.05$ \\
\hline $\begin{array}{l}\text { Aspergillus } \\
\text { parasiticus }\end{array}$ & - & - & - & - & - & 833 & - & - & $104 \pm 0.1$ \\
\hline Rhizopus sp. & 333 & - & - & - & - & - & - & - & $41 \pm 0.04$ \\
\hline $\begin{array}{c}\text { Cladosporium } \\
\text { sp. }\end{array}$ & - & - & 332 & - & - & - & - & - & $41 \pm 0.02$ \\
\hline
\end{tabular}

$(c f u / g) *=$ colony forming unit.

After isolation and counting of the colonies was done A. parasiticus, A. tamarIi, T. harzianum and pencillium sp. are selected to test their virulence against the third larval instar of the cotton leaf worm through recording the mortality percentage for each fungus using $\left(1 \times 10^{6}, 1 \times 10^{7}\right.$ and $1 \times 10^{8}$ conidial spore $/ \mathrm{ml}$ ).

\section{Virulence test of the isolated entomopathogenic fungi against $3^{\text {rd }}$ instar larvae of Spodoptera littoralis.}

In the current study four of well-known entomon pathogenic fungi were tested for virulance against $S$. littoralis larvae. These are A.tamarii, A.parasiticus, Pencillium sp., and T. harzianum.

The virulence of fungal entomopathogens involves four steps: adhesion, germination, differentiation and penetration. Each step is influenced by a range of integrated intrinsic and external factors, which ultimately determine the pathogenicity. The virulence of an entomopathogenic fungus is recognized first by adhesion to an insect body. The failure of a pathogen to adhere with the epidermis is considered a feature of virulent strains (Al-Aidroos and Roberts, 1978). After adhesion, the next factor for the virulence of a strain is the enzymes that hydrolyze the epidermis of the insect. The most important enzymes secreted by entomopathogenic fungi are lipases, proteases and chitinases, which are produced sequentially, reflecting the order of the substrates they encounter (Smith et al., 1981). A wide range of factors such as water, ions, fatty acids and nutrients on the cuticle surface and the physiological state of the host, influence spore germination and behavior (Hassan et al., 1989). Successful germination requires the assimilation of utilizable nutrients and 
a tolerance to any toxic compound present on the surface. After germination, appresoria appear at the end of short germ tubes, subterminally or on the side branches. Penetration of the cuticle is accomplished by the germ tube itself or by the formation of an appressorium that attaches to the cuticle and gives rise to a narrow penetration peg (Boucias and Pendland, 1982; Roberts and Humber, 1981; Wraight et al., 1998; Zacharuk, 1973). The penetration process is considered to be a combination of enzymatic and mechanical forces. The exact mechanism for entry is usually peculiar to the species. A range of cuticledegrading enzymes is produced during penetration into the host (Gillespie et al., 1988).

Eventually, it emerges into the haemocoel of the host, and consequently, grows inside the haemocoel as yeast-like blastospores, hyphal bodies or protoplasts. This may occur if the fungus has the ability to produce immune suppressors that block the host defensive immune responses, and consequently,kills the host by disrupting its physiological processes and/or consuming nutrients in the haemolymph (Samson, et al., 1988), as well as hydrophobic and electrostatic forces also play a role (Boucias et al., 1998).
Table (4) show that the mortality percentage in

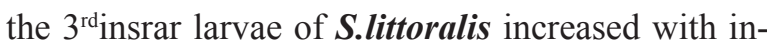
creasing time elapsed after treatment with $\boldsymbol{T}$. harizianum. Highest mortality percentage $80 \%$ recorded at conidial concentration $\left(1 \times 10^{6}\right.$ spores $\left./ \mathrm{ml}\right)$. The observed mortality may be because Trichoderma are known to produce a number of antibiotics, such as trichodermin , trichodermol, harzianum A, harzianolide and peptaibols (Claydon, et al., 1991, Dickinson, et al., 1995 and Hoell et al., 2005). These components are proved to be insecticidal when fed to larvae of S.littoralis or when applied to the cuticle together with the serine protease. Thus Shakeri and Foster (2007) suggested these components as virulence factors involved in insect pathogenicity. Therefore, it suggested that enzymatic and antibiotic activities detected from Trichoderma could have occurred by one or all of these compounds. Also, Ahmed and El-Katatny (2007) results confirm this study, the results stated that $80 \%$ larval mortality occurred at a minimum concentration of $1 \times 10^{8}$ conidia ml- 1 of Trichoderma harizianum.

Table (4) : Mortality percentage of third instars larvae of Spodoptera littoralis after feeding on treated castor bean leaves immersed in different concentrations of Trichoderma harizianum after different periods.

\begin{tabular}{|c|c|c|c|c|c|c|c|c|}
\hline \multirow{2}{*}{$\begin{array}{c}\text { Conc. } \\
\text { (spore /ml) }\end{array}$} & \multicolumn{6}{|c|}{$\begin{array}{c}\text { Mortality \% } \\
\text { Indicated days after treatments }\end{array}$} & \multirow{2}{*}{$\begin{array}{c}\text { Total } \\
\text { Mortality\% }\end{array}$} \\
\cline { 2 - 9 } & 2 & 4 & 6 & 8 & 10 & 12 & 14 & \\
\hline Control & 0 & 0 & 0 & 1 & 8.33 & 9.66 & 9.66 & $\mathbf{9 . 6 6}^{\mathbf{b}}$ \\
\hline $\mathbf{1 0}^{\mathbf{6}}$ & 0 & 3.33 & 16.66 & 26.66 & 33.33 & 63.33 & 80 & $\mathbf{8 0}^{\mathbf{a}}$ \\
\hline $\mathbf{1 0}^{\mathbf{7}}$ & 3.33 & 13.33 & 23.33 & 30 & 40 & 53.33 & 73.33 & $\mathbf{7 3 . 3 3}^{\mathrm{a}}$ \\
\hline $\mathbf{1 0}^{\mathbf{8}}$ & 3.33 & 3.33 & 13.33 & 33.33 & 33.33 & 43.33 & 50 & $\mathbf{5 0}^{\mathbf{a}}$ \\
\hline
\end{tabular}

Values followed by the same letter in last column are not significantly different at $P>0.05$. 
Tables (5) show the mortality percentage in the

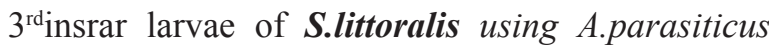
spore suspension. Comparison between total mortality percentage recorded with three diffferent concentrations $\left(10^{6}, 10^{7}, 10^{8}\right)$ spore suspension of Aspergillus parasiticus and the control (treating third instar larvae of $\boldsymbol{S}$. littoralis with distilled water) indicated that the spore suspension concentration $10^{7}$ give the best mortality percentage $(83.33 \%)$. Also there is not any significant difference between mortality percentages recorded at different fungus concentrations, while they are significantly differ from control. So $A$. parasiticus can be used as an important biological control agent against $\boldsymbol{S}$. littoralis where it recorded the highest mortality percentage. Shoulkamy et al. (2014) results also agree with these results.

Table (5) : Mortality percentage of third instars larvae of Spodoptera littoralis after feeding on treated castor bean leaves immersed in different concentrations of Aspergillus parasitcus.

\begin{tabular}{|c|c|c|c|c|c|c|c|c|}
\hline \multirow{2}{*}{$\begin{array}{c}\text { Conc. } \\
\text { (spore } / \mathrm{ml})\end{array}$} & \multicolumn{7}{|c|}{$\begin{array}{c}\text { Mortality \% } \\
\text { Indicated days after treatments }\end{array}$} & \multirow{2}{*}{$\begin{array}{c}\text { Total } \\
\text { Mortality\% }\end{array}$} \\
\hline & 2 & 4 & 6 & 8 & 10 & 12 & 14 & \\
\hline Control & 0 & 0 & 0 & 1 & 8.33 & 9.66 & 9.66 & $9.66^{b}$ \\
\hline 106 & 0 & 0 & 0 & 3 & 3 & 33 & 66.33 & $66.33^{a}$ \\
\hline 107 & 0 & 0 & 0 & 6.66 & 30 & 56.66 & 83.33 & 83.33 a \\
\hline $10^{8}$ & 3.33 & 3.33 & 6.66 & 6.66 & 16.66 & 40 & 76.66 & $76.66^{a}$ \\
\hline
\end{tabular}

Values followed by the same letter in last column are not significantly different at $P>0.05$ LSD $0.05=38.819638873$

Table (6) Show the recorded mortality percentages of third instars larvae of $\boldsymbol{S}$. littoralis after feeding on treated castor bean leaves immersed in different concentrations of $A$. tamarii. comparison between total mortality percentages recorded cleared best mortality percentage $(86.66 \%)$ then $10^{6}$ give $(60 \%)$ and $10^{7}$ give $(43.33 \%)$ incrossponding to control $(9.66 \%)$,and increasing the elapsed time from12 to14 days doesn't increase the mortality percentage, it remain the same. that a spore suspension concentration $10^{8}$ give the

Table (6) : Mortality percentage of third instars larvae of Spodoptera littoralis after feeding on treated castor bean leaves immersed in different concentrations of Aspergillus tamarii.

\begin{tabular}{|c|c|c|c|c|c|c|c|c|}
\hline \multirow{2}{*}{$\begin{array}{c}\text { Conc. } \\
\text { ( spore /ml) }\end{array}$} & \multicolumn{7}{|c|}{ Morality \% } & \multirow{2}{*}{$\begin{array}{c}\text { Total } \\
\text { Mortality\% }\end{array}$} \\
\cline { 2 - 9 } & 2 & 4 & 6 & 8 & 10 & 12 & 14 & \\
\hline Control & 0 & 0 & 0 & 1 & 8.33 & 9.66 & 9.66 & $\mathbf{9 . 6 6}^{\text {b }}$ \\
\hline $\mathbf{1 0}^{\mathbf{6}}$ & 0 & 10 & 10 & 13 & 36.66 & 60 & 60 & $\mathbf{6 0}^{\text {a }}$ \\
\hline $\mathbf{1 0}^{\mathbf{7}}$ & 0 & 0 & 3.33 & 3.33 & 30 & 43.33 & 43.33 & $\mathbf{4 3 . 3 3}^{\text {ab }}$ \\
\hline $\mathbf{1 0}^{\mathbf{8}}$ & 0 & 10 & 10 & 26.66 & 46.66 & 86.66 & 86.66 & $\mathbf{8 6 . 6 6}^{\text {a }}$ \\
\hline
\end{tabular}

Values followed by the same letter in last column are not significantly different at $P>0.05$ 
Table (7) show mortality percentage of third instars larvae of S.littoralis after feeding on treated castor bean leaves immersed in different concentrations of Pencillium sp. The obtained results indicated that by increasing both concentrations and elapsed time the mortality recorded did not significantly increase and the highest one was $40 \%$ at concentration of $10^{7}$ and 14 days post treatment. These results also show that Pencillium sp. has the lowest mortality percentage recorded compared to the remaining fungal strains .
Generally, the results of four tested fungus indicated that the mortality percentage increased with time, this is because the fungi need more time to adhere the insect cuticle, penetrate and complete its cycle inside the insect body. Asi et al. (2009) results agree with our results, he found that the mortality of the aphids increased with increase in spore concentration and exposure time. Also, Ansari et al. (2004) found that recorded mortality depended on the concentration of conidial suspension, exposure time and temperature. The susceptibility of same aphid species may vary to different fungal strains.

Table (7) : Mortality percentage of third instars larvae of Spodoptera littoralis after feeding on treated castor bean leaves immersed in different concentrations of Pencillium $s p$.

\begin{tabular}{|c|c|c|c|c|c|c|c|c|}
\hline \multirow{2}{*}{$\begin{array}{c}\text { Conc. } \\
(\text { spore } / \mathbf{m l})\end{array}$} & \multicolumn{6}{|c|}{ Mortality \% } & \multirow{2}{*}{$\begin{array}{c}\text { Total } \\
\text { Indicated days after treatments }\end{array}$} \\
\cline { 2 - 9 } & 2 & 4 & 6 & 8 & 10 & 12 & 14 & \\
\hline Control & 0 & 0 & 0 & 1 & 8.33 & 9.66 & 9.66 & $\mathbf{9 . 6 6}^{\text {a }}$ \\
\hline $\mathbf{1 0}^{\mathbf{6}}$ & 3.33 & 3.33 & 6.66 & 20 & 30 & 36.6 & 36.6 & $\mathbf{3 6 . 6}^{\text {a }}$ \\
\hline $\mathbf{1 0}^{\mathbf{7}}$ & 0 & 0 & 6.66 & 13.3 & 30 & 40 & 40 & $\mathbf{4 0}^{\text {a }}$ \\
\hline $\mathbf{1 0}^{\mathbf{8}}$ & 0 & 0 & 3.33 & 10 & 30 & 33.33 & 33.33 & $\mathbf{3 3 . 3 3}^{\text {a }}$ \\
\hline
\end{tabular}

Values followed by the same letter in last column are not significantly different at $P>0.05$ LSD $0.05=51.279434795$

\section{Primary screening of the isolated fungi for protease enzyme production}

It is clear from the screening that all of the isolates produce protease enzyme except Penicillium sp. Aspergillus tamarii gave the highest percentage recorded. comparison between total mortality percentages recorded cleared that a spore suspension concentration $10^{8}$ give the best mortality percentage $(86.66 \%)$ then $10^{6}$ give $(60 \%)$ and $10^{7}$ give $(43.33 \%)$ incrossponding to control $(9.66 \%)$ ). The lowest mortality percentage was at concentration of $1 \times 10^{7}$ so, gamma irradiation was used to enhance the protease enzyme activity and concesequantly increase the lowest mortality percentage. From the results it is clear that the dose 1200 Gy increase protease activity of $A$. tamarii from 0.433 to 1.366 so mortality per- centage of third instar larvae of Spodoptera littoralis increased from $43.33 \%$ to $86.66 \%$ at concentration $1 \times 10^{7}$ of spore suspension irradiated with $1200 \mathrm{~Gy}$.

Table (8): show the effect of exposing spore suspension $\left(1 \times 10^{7}\right)$ of A.tamarii to gamma-irradiation at $400,600,800,1000$ and $1200 \mathrm{~Gy}$. It appears that exposing $A$. tamarii to gamma-irradiation at dose 400,600 and 1200 Gy increase production of protease enzyme. A dose of 1000 Gy decrease protease enzyme activity and 800 Gy make the fungus unable to produce protease enzyme, while it was still not differ significantly from each other. So dose level $1200 \mathrm{~Gy}$ is the best one that increase protease enzyme activity and thus was significantly differ from other treatments and control. 
Table (8) : Effect of gamma radiation on Aspergillus tamarii protease enzyme production and activity.

\begin{tabular}{|c|c|}
\hline Dose & Enzyme activity \\
\hline control & $0.433^{\mathrm{c}}$ \\
\hline $\mathbf{4 0 0 G y}$ & $0.811^{\mathrm{b}}$ \\
\hline $\mathbf{6 0 0 G y}$ & $0.693^{\mathrm{bc}}$ \\
\hline $\mathbf{8 0 0 G y}$ & $0^{\mathrm{d}}$ \\
\hline $\mathbf{1 0 0 0 G y}$ & $0.3^{\text {cd }}$ \\
\hline $\mathbf{1 2 0 0 G y}$ & $1.366^{\mathrm{a}}$ \\
\hline
\end{tabular}

LSD $0.05=045275853315$

From data in table (8) it is clear that gamma radiation was used to enhance the protease enzyme activity, the dose of 1200 Gy increase protease activity of A. tamarii from 0.433 to 1.366 .Mortality per- centage of third instar larvae of Spodoptera littoralis increased from $43.33 \%$ to $86.66 \%$ at concentration $1 \times 10^{7}$ of spore suspension irradiated with $1200 \mathrm{~Gy}$ (Table 9 ).

Table (9) : Comparison between the mortality percentage of third instar larvae of Spodoptera littoralis treated with normal and irradiated spore suspension of A. tamarii.

\begin{tabular}{|c|c|c|c|c|c|c|c|c|}
\hline \multirow{2}{*}{$\begin{array}{c}\text { Conc. } \\
\text { spore /ml) }\end{array}$} & \multicolumn{7}{|c|}{ Mortality \% } & \multirow{2}{*}{$\begin{array}{c}\text { Total } \\
\text { Indicated days after treatments }\end{array}$} \\
\cline { 2 - 9 } & 2 & 4 & 6 & 8 & 10 & 12 & 14 & \\
\hline $\begin{array}{c}10^{7} \text { normal } \\
\text { spore } \\
\text { suspension }\end{array}$ & 0 & 0 & 3.33 & 3.33 & 30 & 43.3 & 43.3 & 43.3 \\
\hline $\begin{array}{c}10^{7} \text { irradiated } \\
\text { spore } \\
\text { suspension } \\
(1200 G Y)\end{array}$ & 23.33 & 26.66 & 26.66 & 40 & 56.66 & 63.33 & 86.66 & 86.66 \\
\hline
\end{tabular}

Protease activity can determine the virulence of entomopathogenic fungi to some degree, thus can be used as a virulence index (St-Leger et al., 1987; St-Leger et al., 1996; Feng, 1998; Gillespie et al., 1998; Castellanos-Moguel et al., 2008). However, there are other studies in which, no reliable relationship between the protease activity and virulence of studied entomopathogenic fungi has been estabe lished (Gillespie et al., 1998; Vargas et al., 2003; Dias et al., 2008).
Gamma radiation used to increase the activity of protease enzyme and consequently to increase the mortality percentage of the fungi that has lower mortality percentage. Smith (1958) compiled a paper on using of radiation to produce useful mutations based on papers presented in three symposia in the United States from August 1956 to January1957. Casarett (1968) reported that, radiation doses required to proe duce measurable change in the common catabolic processes are higher than that necessary to decrease 
survival cells of microorganisms. Olive (1998) proved that, ionizing radiation produces many types of DNA lesions that have the potential of killing microbial cells. Gherbawy (1998) studied the efe fect of gamma irradiation on the production of cell wall degrading enzymes by Aspergillus niger.The impact of gamma radiation on the metabolic activities of microorganisms differs as it may be negative (Jones et al., 2004) or positive effect (Haggag and Mohamed, 2002).

\section{CONCLUSION}

The results obtained in this study indicated that the high mortality percentages recorded for $A$. tamarii is $86.66 \%$ at concentration of $1 \times 10^{8}$ spore / $\mathrm{ml}, 83.33 \%$ for $A$. parasiticus at $1 \times 10^{7}$ spore $/ \mathrm{ml}$, for T. harizianum $80 \%$ at $1 \times 10^{6}$ spore $/ \mathrm{ml}$ and $40 \%$ at $1 \times 10^{7} \mathrm{spore} / \mathrm{ml}$ for Pencillium sp. It is clear form mentioned results that the best fungus that kills the cotton leaf worm is A. tamarii and the least one is Pencillium sp. Gamma irradiation can be used to enhance the activity of the fungal enzyme and this will increase their virulence against cotton leaf worm. Thus we can conclude that entomopathogenic fungi play a major role in the regulation of Spodoptera littoralis pest population and it's management.

\section{REFERENCES}

- Ahmed, A.M. and El-Katatny, M.H. (2007): Entomopathogenic fungi as bio bestisides against the Egyption cotton leaf worm,Spodoptera littoralis : between bio control promise and immune -limitation. $J$. Egypt. Soc. Toxicol., 37: 39.

- Al-Aidoors, K. and Roberts, D.W. (1978): Mutants of Metarhizium anisopliae with increased virulence toward mosquito larvae. Can. J. Gen \& Cyt., 11: 211.

- Amer, M.M.; El-Sayed, T.I.; Bakheit, H.K.; Moustafa, S.A.and El-Sayed, Y.A. (2008): Pathogenicity and genetic variability of five entomopathogenic fungi against Spodoptera littoralis. Res. J. Agri. Sci., 4(5): 354 .
- Amin, N.; Daha, L. and Agus, N. (2014): The Study on the role of entomopathogenic fungal endophytes in controling the Pod Borer (Conopomorpha cramerella (Snellen)) (Lepidoptera: Gracillariidea) on Cocoa Plant. J. Entomology., 11(3):142.

- Anagnostakis (1975): Use of solid media for detection of enzyme production by fungi. Mycologia, 597.

- Anand, R. and Tiwary, B.N. (2009): Pathogenicity of entomopathogenic fungi to eggs and larvae of Spodoptera litura, the common cutworm. Biocon. Sci. Tech., 19(9): 19.

- Anand, R.; Prasad, B. and Tiwary, B.N. (2008): Relative susceptibility of Spodoptera litura pupae to elected entomopathogenic fungi. Biocontrol, 54(1): 85.

- Ansari, M.A.; Vestergaard, S.; Tirry, L. and Moensa, M. (2004): Selection of a highly virulent fungal isolates, Metarhizium anisopliae CLO 53, for controlling Hoplia philanthus. J. Invertebr. Pathol., 85(2): 89 .

- $\quad$ Arx J.V.; Guarro J. and Figueras, M.J. (1986): The ascomycete genus Chaetomium. Nova Hedwigia Beihefte., 84(1):162.

- Arx, J.V. (1981): The genera of fungi sporulating in pure culture. 3rd Ed. J. Cramer, Vaduz. 424.

- Asi, M.R.; Bashir, M.H.; Afzal, M. and Imran, S. (2009): Effect of conidial concentration of entomopathogenic fungi on mortality of cabbage aphid, Brevicoryne brassicae L. Pak. J. Life. Soc. Sci., 2: 175.

- Bin, W. and Mitsuaki, S. (2006): Density dynamics of an entomopathogenic fungus, Beauveria bassiana introduced into fresh water. Bulletin of FFPRI, 5: 227.

- Boucias, D.G. and Pendland, J.C. (1982); Ultrastructural studies on the fungus, Nomuraea rileyi, infecting the velvet bean caterpillar, Anticarsia gemmatalis. J. Invertebr. Pathol., 39: 338.

- Boucias, D.G.; Farmerie, W. G. and Pendland, J.C. (1998): Cloning and sequencing the cDNA of 
the insecticidal toxin, Hirsutellin A. J. Invertebr. Pathol., 72:258.

- Boucias, D.G.; Farmerie, W.G. and Pendland, J.C. (1998): Cloning and sequencing the cDNA of the insecticidal toxin, Hirsutellin A. J. Invertebr. Pathol, $72: 258$.

- Casarelett, A.P. (1968): Radiation biology .United States. Atomic energy commission, Washinbon D.C, U.S.A.

- Castellanos-Moguel, J.; Cruz-Camarillo, R.; Aranda, E.; Mier, T. and Toriello, C. (2008): Relationship between protease and chitinase activity and the virulence of Paecilomyces fumosoroseus in Trialeurodes vaporariorum (Hemiptera: Aleyrodidae). Rev. Mex. Mico., 28: 73.

- Charnley, A.K. (1984): Physiological aspects of destructive pathogenesis in insects by fungi: A speculative review. In "Invertebrate-Microbial Interactions" (J.M. Andersonn, A. DM, Rayner, and DWH Walton etc.). British Mycological Society Symposium 6, Cambridge Univ. Press, London, pp. 229.

- Claydon, N.; Hanson, J. R.; Truneh, A. and Avent, A.G. (1991): Harzianolide, a butenolide metabolite from cultures of Trichoderm harzianum. Phy. Chem., $30: 3802$.

- Dias, B.A.; Neves, P.M.; Furlaneto-Maia, L. and Furlaneto, M.C. (2008): Cuticle degrading proteases produced by the entomopathogenic fungus Beauveria bassiana in the presence of coffee berry borer cuticle. Braz. Micr., 39: 301.

- Dickinson, J.M.; Hanson, J.R. and Trunch, A. (1995): Ametabolites of some biological control agents. Pest. Sci., 44: 389.

- Domsch K.H.; Gams W.; Anderson, T.H. (1980): Compendium of soil fungi. London, England: Academic Press. 865 p.

- $\quad$ Elliot, S.L.; Sabelis, M.W.; and Janssen, A. (2000): Can plants use entomopathogens as bodyguards? Ecol. Lett. van der Geest LPS, J. Beerling EAM, Fransen, 3:228.
- $\quad$ Ellis, M.B. (1971): Dematiaceous Hyphomycetes. The Commonwealth Mycological Institute, England. pp.1.

- $\quad$ Ellis, M.B. (1976): More Dematiaceous Hyphomycetes. The Commonwealth Mycological Institute, England. pp.1.

- Evans, H.C. (1999): Biological control of weed and insect pests using fungal pathogens, with particular reference to Biocon. News \& Inform. 20(2): 63.

- $\quad$ Feng, M.G. (1998): Reliability of extracellular protease and lipase activities of Beauveria bassiana isolates used as their virulence indices. Acta. Micr. Sini., 38: 461 .

- $\quad$ Ferron, P. (1978): Biological control of insect pests by entomopathogenic fungi. Ann. Rev. Entom., 23: 409.

- Ferron, P. (1981): Pest control by the fungi Beauveria and metarhizium, In: Microbiol control of pest plant diseases, H.D Burges (Eds.). 465.

- Gherbawy, A.M.H. (1998): Effect of gamma irradiation on the production of cell wall degrading enzymes by Aspergillus niger. Int. J. Foo.Mic.bio., 40: 127.

- Gillespie, J.P.; Bateman, R. and Charnley, A.K. (1998): Role of cuticle-degrading protease in the virulence of Metarhizium spp. for the desert locust, Schistocerca gregaria. J. Invertebr. Pathol., 71: 128.

- Haggag, W.M. and Mohmed, H.A.A. (2002): Enhancement of antifungal metabolites production from gamma-ray induced mutants of some Trichoderma Species for control onion white rot disease. Plan. Patho. Bull., 11:45.

- Hajek, A.E. and St. Leger. R.J. (1994): Interactions between fungal pathogens and insect hosts. Ann. Rev. Entom., 39: 293.

- Hassan, A.E.M.; Dillion, R.J.; and Charnley, A.K. (1989): Influence of accelerated germination of conidia on the pathogenicity of Metarhizium anisopliae for Manduca sexta. J. Invertbr. Pathol, 54: 227.

- Hicks, B.J.; Watt, A.D. and Cosens, D. (2001): The potential of Beauveria bassiana (Hyphomycetes: 
Moniliales) as a biological control agent against the pine beauty moth, Panolisammea (Lepidoptera: Noctuidae). Fore. Eco.\&Manage., 149: 275.

- Hidalgo, E.; Moore, D. and Le Patourel, G. (1998): The effect of different formulations of Beauveria bassiana on Sitophilus zeamais in stored maize. J. Stor. Prod. Res., 34: 171.

- Hoell, I.A.; Klemsdal, S.S.; Vaaje-Kolstad, G.; Horn, S.J. and Eijsink, V.G.H. (2005): Over expression and characterization of a novel chitinase from Trichoderma atroviride strain P1. Bio. Chim.\& Bio. Phys. Acta., 1748: 180.

- Ismail, M. and Abdel-Sater, M.A. (1993): Fungi associated with the Egyptian cottonleaf worm Spodoptera littoralis Boisdoval. Mycopathologia, 124(2):79.

- Johnson, L.F.; Curl, E.A.; Bond, J.H. and Fri; bourg, H.A. (1960): Method for studying soil microflora - plant disease relationship. Burgess publishing Co. Minneapolis, USA.

- Jones, H.E.; West, H.M.; Chamberlain, P.M.; Parekh, N.R.; Beresford, N.A. and Crout, N.M.J. (2004): Effects of gamma irradiation on Holcus lanatus (Yorkshire fog grass) and associated soil microorganisms. J. Envir. Rad. Acti., 74: 57.

- Kirk, P.M.; Cannon, P.F.; David, J.C. and Stalpers, J.A. (2001): Ainsworth \& Bisby's dictionary of the fungi. $9^{\text {th }}$ edition. CABI Publishing, Wallingford.

- $\quad$ Lacey, L.A.; Frutos, R.; Kaya, H.K. and Vails, P. (2001): Insect pathogens as biological control agents: Do they have future? Biocontrol. J., 21(3): 230.

- Leatherdale, D. (1970): The arthropod hosts of entomopathogenic fungi in Britain. Entomophaga, 15: 419.

- Lin, H.P.; Yang, X.J.; Gao, Y.B. and Li, S.G. (2007): Pathogenicity of several fungal species on Spodoptera litura.Chinse J. Appl. Eco., 18(4): 937.

- Malikarjuna, N.; Kranthi, K.R.; Jadhav, D.R.; Kranthi, S. and Chandra, S. (2004): Influence of foliar chemical compounds on the development of Spodoptera litura (Fab.) in inter-specific derivatives of groundnut. J. Appl. Entom., 128: 321.

- Mustafa, U. and Kaur, G. (2009): Extracellular enzyme production in Metarhizium anisopliae isolates. Folia. Mic., 54(6):499.

- Nguyen, N.C.; Borgemeister, H. P. and Zimmermannn, G. (2007): Laboratory investigations on the potential of entomopathogenic fungi for biocontrol of Helicoverpa armigera (Lepidoptera: Noctuidae) larvae and pupae. Biocon. Sci. Tec., 17(12): 853.

- $\quad$ Olive, P. (1998): The role of DNA single and doublestrand breaks in cell killing by ionizing radiation, Rad.Res., 150:42.

- Palomares, J.; Palenius, H.; Avalos, M.; Rangel, A. and Gutiérrez, R. (2014): Ocurrence of entomopathogenic fungus from Flea Ctenocephalides canis (Siphonaptera: Pulicidae). J. Veter. Med., 4: 281.

- Pitt, J.I. (1980): The genus Penicillium and its teleomorphic states Eupenicillium and Talaromyces. London,Academic Press. 634p.

- $\quad$ Purwar, J. P. and Sachan ,G.C.(2005): Biotoxicity of Beauveria bassiana and Metarhizium anisopliae against Spodoptera litura and Spilarctia oblique. Ann. Plan. Prot. Sci., 13(2): 360.

- $\quad$ Raper, K.B. and Thom, C. (1949): A manual of the Penicillia. Baltimore: Williams\& Wilkins Company. $875 \mathrm{p}$.

- Roberts, D.W., and Humber, R.A. (1981): Entomogenous fungi. In: Cole GT, Kendrick B, (Eds.), Biology of Conidial Fungi. Academic Press, New York, 201.

- Saikkonen, K.; Wali, P.; Helander, M., and Faeth, S.H. (2004): Evolution of endophyte plant symbioses. Tren. Plan.Sci., 9:275.

- $\quad$ Samson, R.A.; Evans, H.C. and Latge, J.P. (1988): Atlas of entomopathogenic fungi. Springer Verlag, Berlin, Germany, pp. 299.

- Samuels, K.D.Z.; Heale, J.B. and Liewellyn, M. (1989): Characteristics relating to the pathogenicity of Metarhizium anisopliae toward Niaparvata lugens. J. Invertebr. Pathol. 53: 25. 
- Shahid, A.A.; Qayyumrao, A.; Bakhash and Husnain (2012): Entomopathogenic fungi as biological controllers: New insights into their virulence and pathogencity. Arch. Bio. Sci., Belgrade, 64 (1): 21.

- Shakeri, J. and Foster, H. A. (2007). Proteolytic activity and antibiotic production by Trichoderma harzianum in relation to pathogenicity to insects. Enz. \& Mic. Tech., 40: 961.

- Shoulkamy, M.A.; Salama, S.A. and Ahmad, S.M. (2014): Use of entomopathogenic fungi for control of the cotton leaf worm, Spodoptera litoralis. J. Jazan Univ .Appl. Sci. Bran., 3 (1): 1.

- Smith, H.H. (1958): Radiation in the production of useful mutations. Bot. Rev., 24: 1.

- $\quad$ Smith, R.J.; Pekrul, S., and Grula, E.A. (1981): Requirement for sequential enzymatic activities for penetration of the integument of the corn earworm. $J$. Invertebr. Pathol., 38: 335.

- Smith, S.M.; Moore, D.; Karanja, L. W. and Chandi, E.A. (1999): Formulation of vegetable fat pellets with pheromone and Beauveria bassiana to control the larger grain borer, Prostephanus truncates (Horn). Pest. Sci., 55: 711.

- $\quad$ St. Leger, R.J.; Durrands, P.K.; Chamely, A.K., and Cooper, R.M. (1988): Role of extracellular chymoelastase in the virulence of Metarhizium anisopliae for Manduca sexta. J. Invertebr. Pathol., 52: 285.

- $\quad$ St-Leger, R.J.; Charnley, A.K. and Cooper, R.M. (1987): Characterization of cuticle degrading proteases produced by the entomopathogen Metarhizium anisopliae. Arch. Biochem. \& Biophys., 253: 221.

- $\quad$ St-Leger, R.J.; Joshi, L.; Bidochka, M. J.; Rizzo,
N. and Roberts, D.W. (1996): Biochemical characterization and ultrastructural localization of two extracellular trypsins produced by Metarhizium anisopliae in infected insect cuticles. Appl. \& Envir.Micr., 62: 1257.

- Thom, C.; Raper, K.B., (1945): Manual of the Aspergilli.Williams and Wilkins, Baltimore.

- Ujian, A.A. and Shahzad, S.. (2007): Pathogenicity of Metarhizium anisopliae, Var.Acridum strains on Pink Hibiscus Mealy bug (Maconellicoccus hirsutus) affecting cotton crop. Pakist. J. Bot., 39 (3): 96.

- Vargas, L.B.; Rossato, M.; Ribeir, R. S. and de Barros, N.M. (2003): Characterization of Nomuraea rileyi strains using polymorphic DNA, virulence and enzyme activity. Braz. Arch. Bio \& Tech., 46: 13.

- White, J.F.; Belanger, F.; Meyer, W.; Sullivan, R.F.; Bischoff, J.F., and Lewis, E.A. (2002): Clavicipitalean fungal epibionts and endophytes developi ment of symbiotic interactions with plants. Symbiosis, 33: 201

- Wraight, S.P.; Carruthers, R.I.; Bradely, C.A.; Jaronski, S.T.; Lacey, L.A.; Wood, P., and Galaini, W.S.Z. (1998): Pathogenicity of entomopathogenic fungi Paecilomyces spp. and Beauveria bassiana against silver whitefly, Bemisia argentifolii. J. Invertebr. Pathol., 71:217.

- Zacharuk, R.Y. (1973): Electron-microscope studies of the histopathology of fungal infections by Metarhizium anisopliae. Misc. Pub. Entom. Soc., Amer., 9: 112.

- Zimmerman, G. (1993): The entomopathogenic fungus Metarhizium anisopliae and its potential as a biocontrol agent. Pest. Sci., 37: 375-379. 